\title{
PENGARUH KUALITAS LAYANAN, KOMITMEN PELANGGAN DAN KEPERCAYAAN TERHADAP LOYALITAS PELANGGAN
}

\section{THE EFFECT OF QUALITY OF SERVICES, CUSTOMER AND TRUST COMMITMENT TO CUSTOMER LOYALTY}

\author{
Laili Ika Nafisatin, M. Naely Azhad, Wahyu Eko Setianingsih \\ Fakultas Ekonomi Universitas Muhammadiyah Jember \\ Email: naelyazhad@unmuhjember.ac.id dan setianingsih@unmuhjember.ac.id
}

\begin{abstract}
ABSTRAK
Penelitian ini dilakukan pada pelanggan swalayan Larisso Ambulu Jember. Penelitian ini bertujuan untuk mengetahui pengaruh dari kualitas layanan, komitmen pelanggan dan kepercayaan pelanggan terhadap loyalitas pelanggan swalayan Larisso Ambulu Jember. Dalam penelitian ini data dikumpulkan dengan alat bantu berupa observasi, wawancara dan kuesioner terhadap 60 responden dengan teknik purpossive sampling, yang bertujuan untuk mengetahui persepsi responden terhadap masing-masing variabel. Analisis yang digunakan meliputi uji instrumen data (uji validitas, dan uji reliabilitas), analisis regresi linear berganda, dan uji hipotesis (uji $\mathrm{F}$, uji t, koefisien determinasi. Dari hasil analisis menggunakan regresi dapat diketahui bahwa variabel kualitas layanan, komitmen pelanggan dan kepercayaan pelanggan, semuanya berpengaruh positif terhadap loyalitas pelanggan. Dari uji t diperoleh hasil kualitas layanan, komitmen pelanggan dan kepercayaan pelanggan, semuanya berpengaruh signifikan terhadap loyalitas pelanggan. Dari uji $\mathrm{F}$ diperoleh hasil kualitas layanan, komitmen pelanggan dan kepercayaan pelanggan, semuanya berpengaruh signifikan secara simultan terhadap loyalitas pelanggan.
\end{abstract}

Kata Kunci: kualitas layanan, komitmen pelanggan, kepercayaan dan loyalitas pelanggan

ABSTRACT
This research is conducted to customers of Larisso swalyan at Ambulu Jember. The aim from this research is to know the effect from service quality, customer commitmen, and customer trust toward the customer loyalty of Larisso swalyan at Ambulu Jember. In this research collected of data with observation, interview and questionnaire toward 60 respondents with purpossive sampling technique. This is doing to know the perceptions from respondents about each variable. Data instrument test (Validity test, and reliability test), multiple linear regression analysis, classic assumption test (Normality test, Multicolinearity test, heteroskedasticity test), and hypothesis test ( $\mathrm{F}$ test, $\mathrm{t}$ test, determination coefficient) will be used to analyze. From regression analysis, we know that service quality, customer commitmen, and customer trust have the positive effect for the customer loyalty. From $\mathrm{t}$ test resulting quality of service quality, customer commitmen, and customer trust, that mean all of three variables have significance influential toward customer loyalty. From $\mathrm{F}$ test resulting service quality, customer commitmen, and customer trust, that mean all of three variables have simultaneous significance influential toward the customer loyalty. Coeeficient of determination analyze finding 76,9\% from variation customer loyalty can explained by service quality, commitment dan trust and then 0,231 residual explained by another variabel from this research

Key words: service quality, customer commitmen, customer trust, and customer loyalty 


\section{PENDAHULUAN}

Proses perkembangan dunia usaha yang semakin pesat sekarang ini menyebabkan terjadinya persaingan pasar yang semakin ketat. Dengan adanya persaingan pasar ini sebuah organisasi bisnis (perusahaan) dituntut untuk dapat mengambil langkah-langkah yang tepat agar dapat beradaptasi terhadap perubahan iklim usaha yang sangat dinamis. Seiring perkembangan zaman keberadaan bisnis eceran ditengahtengah masyarakat menjadi semakin penting. Hal ini disebabkan karena adanya perubahan dalam pola berbelanja masyarakat yang semakin selektif, selain itu juga karena adanya perubahan cara pandang konsumen terhadap bisnis ritel itu sendiri. Bisnis ritel yang secara tradisional dipandang sebatas penyedia barang dan jasa telah berkembang menjadi tidak sekedar tempat berbelanja tetapi juga tempat rekreasi dan bersosialisasi, sebagai konsekuensinya bisnis ritel yang semula dikelola secara tradisional berubah menjadi bisnis yang semakin inovatif, dinamis, dan kompetitif (Suhartanto dan Nuralia, 2001:27). Perubahan gaya hidup masyarakat inilah yang melatarbelakangi hadir dan berkembangnya bisnis retail

Pandangan tersebut menguatkan pernyataan Berman dan Evans (2001:3) bahwa seorang pengecer berusaha memuaskan pemasok dengan cara membeli beberapa jenis produk mereka yang jumlahnya terbatas akan tetapi dalam jumlah yang lebih besar. Pengecer memuaskan konsumen mereka dengan cara menawarkan berbagai macam jenis barang dan jasa, yang dikumpulkan dari sejumlah sumber, kemudian dijual dalam jumlah yang kecil-kecil. Hal tersebut dapat memengaruhi konsumen dalam melakukan pembelian. Konsumen dan pelanggan merupakan mitra utama bagi pemasar. Pelanggan (customer) berbeda dengan konsumen (consumer), seorang dapat dikatakan sebagai pelanggan apabila orang tersebut mulai membiasakan diri untuk membeli produk atau jasa yang ditawarkan oleh badan usaha. Kebiasaan tersebut dapat dibangun melalui pembelian berulang dalam jangka waktu tertentu. Apabila dalam jangka waktu tertentu tidak melakukan pembelian ulang maka orang tersebut tidak dapat dikatakan sebagai pelanggan tetapi sebagai seorang pembeli (Musanto, 2001:97).

Bagaimana individu atau perusahaaan tersebut dapat dipercaya? Hal inilah yang pertama kali dipikirkan oleh seseorang jika ingin berbisnis dengan orang lain yang belum pernah berbisnis dengannya. Hal ini pula yang dapat dijadikan pedoman oleh perusahaan agar konsumen dapat mempercayai produk yang ditawarkan dan melakukan pembelian 
ulang pada perusahaan tersebut, banyak perusahaan mengandalkan kepuasan konsumen sebagai jaminan keberhasilan di kemudian hari tetapi kemudian kecewa mendapati bahwa para konsumennya yang merasa puas dapat membeli produk pesaing tanpa ragu-ragu. Loyalitas pelanggan secara umum dapat diartikan sebagai kesetiaan seseorang atas suatu produk, baik barang maupun jasa tertentu. Selain itu pelanggan yang memiliki komitmen tinggi akan loyalitasnya tidak akan terpengaruh oleh bentuk-bentuk pemasaran produk atau jasa yang diberikan perusahaan lain dan akan terus memilih produk dan jasa yang mereka pilih sebelumnya. Loyalitas pelanggan akan menjadi kunci sukses, tidak hanya dalam jangka pendek, tetapi keunggulan bersaing yang berkelanjutan (Griffin, 2005:52).

Terdapat beberapa keuntungan strategik bagi perusahaan tentang pentingnya mempertahankan loyalitas pelanggan. Imbalan dari loyalitas bersifat jangka panjang dan kumulatif. Jadi semakin lama loyalitas seoorang konsumen, semakin besar laba yang dapat diperoleh perusahaan dari seorang konsumen yang sangat bernilai bagi organisasi. Dipertahankannya pelanggan yang loyal dapat mengurangi usaha mencari pelanggan baru, memberikan umpan balik positif kepada organisasi, dan loyalitas mempunyai hubungan positif dengan profitabilitas (Dharmmesta, 2005:152). Kotler (2005:241) berpendapat bahwa pelanggan yang puas dan loyal merupakan peluang untuk mendapatkan pelanggan baru. Mempertahankan semua pelanggan yang ada umumnya akan lebih menguntungkan dibandingkan dengan pergantian pelanggan karena biaya untuk menarik pelanggan baru bisa lima kali lipat dari biaya mempertahankan seorang pelanggan yang sudah ada.

Khoe Yao Tung dalam (Saputro, 2010) mengatakan bahwa untuk menggaet satu pelanggan baru diperlukan biaya mulai lima sampai lima belas kali, dibandingkan dengan menjaga hubungan dengan satu pelanggan lama. Di sisi lain, pelanggan yang loyal memberikan banyak keuntungan bagi perusahaan, antara lain: memberikan peluang pembelian ulang yang konsisten, perluasan lini produk yang dikonsumsi, penyebaran berita baik menurunnya elastisitas harga, dan menurunnya biaya promosi dalam rangka menarik pelanggan baru.

Komitmen didefinisikan oleh Moorman, Zalthman, dan Despande (1992:316) dan Zulganef, hubungan antara sikap terhadap bukti fisik, proses dan karyawan dengan kualitas keterhubungan, serta perannya dalam menimbulkan niat ulang membeli dan loyalitas, dalam jurnal riset ekonomi dan manajemen vol 2 no. 3 September 2002, 
menyebutkan sebagai hasrat (desire) untuk mempertahankan keterhubungan dalam jangka panjang (enduring desire). Dalam hal ini ditekankan bahwa komitmen adalah unsur perilaku sebagai upaya untuk memepertahankan dan menjaga hubungan jangka panjang antara kedua belah pihak agar hubungan ini lebih bermakna. Tidak akan terjadi suatu komitmen kalau salah satu atau kedua belah pihak merasa bahwa hubungan tidak menguntungkan. Dengan perkataan lain komitmen berarti di dalamnya terdapat suatu hubungan yang berharga yang perlu dipertahankan terus, dimana masing-masing pihak bersedia bekerja sama untuk mempertankan hubungan ini.

Kualitas layanan merupakan suatu bentuk penilaian konsumen terhadap tingkat layanan yang diterima (perceived service) dengan tingkat layanan yang diharapkan (expected service). Dampak positif dari pelayanan yang baik akan meningkatkan kepuasan dan kesetiaan pelanggan serta keinginan untuk melakukan pembelian kembali (re-buying), yang tentunya akan meningkatkan pendapatan yang diterima dari produk yang telah terjual. Agar dapat bersaing, bertahan hidup, dan berkembang, maka perusahaan dituntut untuk mampu memenuhi kebutuhan dan keinginan pelanggan dengan memberikan pelayanan yang terbaik dan berkualitas, maka dengan begitu pelanggan akan merasa mendapat kepuasan tersendiri dan merasa dihargai sehingga mereka senang dan bersedia untuk menjadi pelanggan tetap (Kotler, 2005:127).

Strategik dari relationship marketing adalah pada banyaknya upaya yang sama besar antara mempertahankan dan menciptakan pelanggan; pada kualitas dan pelayanan pelanggan dan bagaimana kedua elemen itu dapat dikelola sehingga menghilangkan "kesenjangan kualitas" antara apa yang diharapkan pelanggan dengan apa yang pelanggan dapatkan. Dalam pemasaran dibutuhkan komitmen konsumen yang dibangun oleh pemasar yang didalamnya terdapat relationship marketing. Pemahaman yang lebih mendalam tentang relationship marketing dapat ditemukan dalam penelitian yang dilakukan oleh Morgan dan Hunt (1994) yang mengungkapkan aspek kunci berbagai penggerak kerjasama dalam hubungan antara kedua belah pihak, yaitu kepercayaan. Kepercayaan konsumen terhadap penyedia jasa akan meningkatkan nilai hubungan yang terjalin dengan penyedia jasa. Selain itu, tingginya kepercayaan akan dapat berpengaruh terhadap menurunnya kemungkinan untuk melakukan perpindahan terhadap penyedia jasa lain. Dwyer, dkk (Van de Van, 1992) mengemukakan pentingnya kepercayaan untuk membangun suatu hubungan bersama. Menurut Riana (2008) dalam upaya meningkatkan 
loyalitas, pihak perusahaan harus senantiasa meningkatkan dan mempertahankan kepercayaan pelanggan terhadap perusahaan.

Daerah Ambulu memiliki wilayah yang cukup luas, memanjang dari pesisir barat sampai pesisir timur bagian selatan Kabupaten Jember. Di kecamatan Ambulu sendiri terdapat 2 Swalayan yang lokasinya tidak terlalu jauh dan berjarak sekitar $2 \mathrm{Km}$. Alasan memilih lokasi ini dikarenakan daerah kecamatan Ambulu itu sendiri dikarenakan untuk tempat berbelanja sekelas swalayan, daerah Ambulu merupakan rujukan alternatif bagi warga Jember bagian selatan seperti Kencong, Puger, Jenggawah maupun Balung untuk berbelanja. 2 swalayan yang terdapat di Ambulu antara lain adalah Swalayan Larisso dan Swalayan Dyra.

Swalayan Larisso Ambulu Jember adalah salah satu usaha dagang yang dirintis sejak Desember 2012. Swalayan ini merupakan suatu tempat yang dapat menjadi tempat mencari barang-barang kebutuhan sehari-hari seperti sembako, peralatan dapur dan pakaian. Konsep Swalayan Larisso Ambulu Jember dibuat dengan suasana yang sederhana, nyaman, dan santai. Suasana nyaman dan santai tidak hanya dari sisi disain tempat saja, tetapi juga dari kualitas produk, pelayanan yang diberikan, dan harga yang terjangkau. Swalayan Larisso Ambulu Jember menyediakan pilihan yang berkualitas dan beragam dengan harga yang kompetitif. Saat ini Swalayan Larisso Ambulu Jember berlokasi di Jalan Raya Suyitman Ambulu Jember. Dari data penjualan Swalayan Larisso Ambulu Jember mulai bulan Agustus 2015, terjadi kenaikan penjualan pada bulan September 2015 sebesar 7,9\%, pada bulan November naik sebesar 13,5\%, dan pada bulan Desember naik sebesar 2,7\%. Penurunan dialami pada bulan Oktober 2015 sebesar 3,1\%,

Persaingan yang ketat di setiap bidang usaha membuat setiap perusahaan di dalam persaingan tersebut akan mengalami sebuah kenaikan maupun penurunan dalam penjualannya. Begitu pula yang dialami oleh Swalayan Larisso Ambulu Jember, dimana saat ini banyak sekali pesaing bermunculan di area Jember. Dengan fakta tersebut tampak bahwa pesaing Swalayan Larisso Ambulu Jember cukup banyak dan penurunan penjualan bisa juga disebabkan oleh dampak keragaman produk dan kualitas produk yang ditawarkan pesaing. Penurunan jumlah pelanggan ini dapat dikaitkan dengan kualitas layanan yang diberikan oleh Swalayan Larisso Ambulu Jember. Berikut ini hasil wawancara yang dilakukan kepada pelanggan Swalayan Larisso Ambulu Jember yang berjumlah 67 pelanggan. 
Pelanggan yang dikatakan loyal adalah pelanggan yang berbelanja setiap kebutuhannya di larisso lebih 5 kali dalam perbulannya. Dari hasil survey, dapat dilihat bahwa dari 53 survey kepada pelanggan didapatkan fakta bahwa terdapat 14 pelanggan yang berbelanja di larisso lebih dari 5 kali perbulan. 10 pelanggan berbelanja antara 6 - 8 kali perbulan sedangkan sisanya sebanyak 3 pelanggan lebih 9 kali perbulan. Sedangkan yang masih dibawah 5 kali kunjungan adalah 26 pelanggan. Masih ada beberapa pelanggan yang tidak setuju pelanggan berkomitmen kepada Larisso. Hal ini dapat dilihat dari item komitmen yaitu para pelanggan masih merasa produk yang dijual di Larisso dapat dibeli di tempat lain, Larisso bukan tempat utama untuk berbelanja dan tidak mersa mempunyai ikatan emosional dengan Larisso. Begitu juga dengan item kepercayaan, kepercayaan pelanggan terhadap Larisso yang meliputi kemampuan interaksi, dapat dipercaya, sikap terbuka, dan kecakapan. Pelanggan tidak semuanya setuju karena mereka beralasan bahwa masih ada karyawan yang acuh tak acuh walaupun hanya untuk sekedar menyapa, kebenaran informasi yang kadang patut dipertanyakan kebenarannya, tidak adanya kotak kritik dan saran untuk komplain, serta kedekatan yang kurang karyawan terhadap pelanggan. Ini perlu diperhatikan karena pernyataan negatif pada setiap item itu mengacu pada sikap tidak loyal pelanggan.

Beberapa penelitian yang telah dilakukan terkait dengan kualitas layanan, komitmen pelanggan dan kepercayaan pelanggan adalah Lestari (2015), dan Setyani (2014). Penelitian terkait pengaruh kualitas layanan terhadap loyalitas pelanggan pernah dilakukan oleh Setyani (2014). Peneliti tersebut mendapatkan hasil bahwa pelanggan akan merasa puas bila mereka mendapatkan pelayanan yang baik atau yang sesuai dengan yang diharapkan. Kualitas pelayanan yang dberikan dan kepercayaan yang ditawarkan. Kepuasan pelanggan dapat dipenuhi melalui kualitas pelayanan dan kepercayaan yang kompetitif sehingga pelanggan akan melanjutkan transaksi dengan perusahaan tersebut. Kepuasan pelanggan akan terpenuhi apabila mereka memperoleh apa yang mereka inginkan maka akan semakin tinggi tingkat loyalitas pelanggan.

Pengaruh komitmen terhadap loyalitas pelanggan, pernah dilakukan oleh Lestari (2015). Peneliti tersebut mendapatkan hasil bahwa komitmen berpengaruh terhadap loyalitas pelanggan yang artinya konsumen merasa kebutuhan dan keinginannya dapat dengan mudah diperoleh di Swalayan. Karena swalayan ini menyediakan produk rumah 
tangga, sekolah dan kantor dengan lengkap. Sehingga konsumen mempunyai sikap komitmen untuk datang dan melakukan pembelian di masa mendatang.

Penelitian terkait pengaruh kepercayaan terhadap loyalitas pelanggan pernah dilakukan oleh Lestari (2015) Peneliti tersebut mendapatkan hasil bahwa kepercayaan berpengaruh terhadap loyalitas pelanggan yang artinya Swalayan belum cukup cakap dalam menunjukkan rasa hormat kepada konsumen saat memberikan layanan, sehingga pelayanan swalayan ini kurang dapat diandalkan. Selain itu dalam penelitian ini menilai bahwa konsumen merasa Swalayan dalam memasang harga relatif sama dengan swalayan lainnya yang berada di sekitar Pabelan. Sehingga konsumen menilai harga tidak menjadi pembanding dalam menentukan swalayan yang akan dikunjunginya..

\section{TINJAUAN PUSTAKA}

\section{Loyalitas Pelanggan}

Loyalitas berarti kemampuan perusahaan memposisikan produknya di benak konsumen, dimana perusahaan berusaha menganggap konsumen sebagai mitranya dengan cara memantapkan keyakinan pelanggan, selalu berinteraksi, bila perlu mengembangkan, demi kemajuan bersama (Kertajaya, 1999). Sedangkan yang dimaksud dengan konsumen yang loyal atau setia adalah seseorang yang melakukan pembelian ulang dari perusahaan yang sama, memberitahukan ke konsumen yang lain yang potensial dari mulut ke mulut dan menjadi penangkal serangan dari pesaingnya (Evan dan Laskin, 1994). Dengan demikian, dapatlah dikatakan bahwa keberhasilan suatu perusahaan sangatlah ditentukan oleh loyalitas konsumennya.

Loyalitas pelanggan merupakan tingkat komitmen psikologis terhadap suatu produk (Horton dalam Suryani, 1997). Artinya, pelanggan akan setia pada produk tertentu kalau merasa senang dan menyukainya. Jacoby dan Kryner (Ismarrahmini dan Brotoharsojo, 2005) mendefinisikan loyalitas pelanggan sebagai pembelian yang bersifat acak, terungkap terus menerus oleh unit pengambilan keputusan dengan memperhatikan satu atau beberapa produk alternatif dari sejumlah produk sejenis dan merupakan fungsi proses psikologis loyalitas pelanggan selalu berkaitan dengan kecenderungan pelanggan dan pembelian aktual meskipun bobot relatif yang diberikan pada kedua variabel itu dapat berbeda, bergantung pada bidang produk yang terlibat dan faktor situasional yang ada pada saat pembelian tertentu dilakukan. 


\section{Kualitas Layanan}

Service Quality adalah seberapa jauh perbedaan antara harapan dan kenyataan para pelanggan atas layanan yang mereka terima. Service Quality dapat diketahui dengan cara membandingkan persepsi pelanggan atas layanan yang benar-benar mereka terima dengan layanan sesungguhnya yang mereka harapkan. Kualitas pelayanan menjadi hal utama yang diperhatikan serius oleh perusahaan, yang melibatkan seluruh sumber daya yang dimiliki perusahaan. Definisi mutu jasa berpusat pada pemenuhan kebutuhan dan keinginan pelanggan serta ketepatan penyampaian untuk mengimbangi harapan pelanggan (Lupiyoadi, 2004).

Mengacu pada pengertian kualitas layanan tersebut maka konsep kualitas layanan adalah suatu daya tanggap dan realitas dari jasa yang diberikan perusahaan. Kualitas pelayanan harus dimulai dari kebutuhan pelanggan dan berakhir pada persepsi pelanggan (Kotler, 2005). Hal ini berarti bahwa kualitas yang baik bukanlah berdasarkan persepsi penyediaan jasa, melainkan berdasarkan persepsi pelanggan.

\section{Komitmen Pelanggan}

Bowen dan Shoemaker (1998) mengungkapkan bahwa dalam perkembangan terbaru, industri bisnis kini lebih banyak menggunakan pendekatan relationship marketing dibanding pendekatan transaksional. Hal tersebut patut dipahami mengingat pendekatan transaksional memiliki banyak kelemahan, antara lain pendekatan tersebut mudah ditiru oleh pesaing. Sedangkan pendekatan relationship marketing akan mendapatkan pelanggan yang loyal, dimana hal tersebut tidak mudah ditiru oleh pesaing. Agar lebih jelas dalam memahami relationship marketing, berikut dapat dilihat perbandingan antara relationship marketing dengan pemasaran tradisional yang lebih menekankan pada pemasaran transaksional. Anderson dan Weitz (1992) menyatakan bahwa komitmen terdiri dari tiga dimensi, yaitu sebuah hasrat untuk membangun hubungan yang stabil, kemauan untuk memberikan pengorbanan dalam membangun suatu hubungan, dan kepercayaan dalam hubungan yang stabil.

\section{Kepercayaan}

Kepercayaan adalah kesediaan perusahaan untuk bergantung pada mitra bisnis (Kotler, 2007). Kepercayaan tergantung pada sejumlah faktor antarpribadi dan antarorganisasi, seperti kompetensi, integritas, kejujuran, dan kebaikan hati perusahaan. Menurut Morgan dan Hunt dalam Suhardi (2006) mendefinisikan kepercayaan sebagai 
suatu kondisi ketika salah satu pihak yang terlibat dalam proses pertukaran yakin dengan kehandalan dan integritas pihak yang lain. Kuntari (2003) mendefinisikan kepercayaan sebagai mempercayakan seseorang atau sesuatu untuk menjaga kepentingannya, kepercayaan disini bersandar pada seseorang atau sesuatu yang dipercayai mempunyai konsekuensi dalam hubungan diantara pemberi kepercayaan dan yang diberikan kepercayaan. Dalam membangun hubungan tersebut menimbulkan konsekuensi dan implikasi.

\section{Perdagangan Eceran (Retail Business)}

Philip Kotler (2000:592) menyatakan bahwa pengecer (retailer) adalah usaha penjualan eceran meliputi semua kegiatan yang terlibat dalam penjualan barang dan jasa secara langsung ke konsumen akhir untuk penggunaan pribadi dan bukan bisnis. Pengecer atau toko adalah usaha bisnis yang volume penjualannya berasa dari penjualan eceran.

\section{METODE PENELITIAN}

\section{Variabel Penelitian}

Variabel independen independen yaitu variabel yang sering disebut sebagai variabel stimulus, prediktor, ataupun antecedent (penyebab). Dalam bahasa indonesia sering disebut sebagai variabel bebas. Variabel bebas adalah merupakan variabel yang memengaruhi atau yang menjadi sebab perubahannya atau timbulnya variabel dependen/terikat (Sugiyono, 2012). Variabel independen/bebas dalam penelitian ini meliputi: kualitas layanan, komitmen dan kepercayaan.

Variabel terikat merupakan variabel output, kriteria, dan konsekuen. Dalam Bahasa Indonesia sering disebut sebagai variabel terikat. Variabel terikat merupakan variabel yang dipengaruhi atau yang menjadi akibat, karena adanya variabel bebas (Sugiyono, 2012). Variabel dependen/terikat dalam penelitian ini adalah loyalitas pelanggan.

\section{Desain Penelitian}

Dalam merancang suatu penelitian, dikenal penelitian ekploratoris dan konklusif, dimana penelitian konklusif dapat diklasifikasikan lagi atas penelitian diskriptif dan 
kausal. Jika dilihat dari variabelnya yaitu variabel bebas dan terikat, penelitian ini adalah penelitian kausalitas. Penelitian kausalitas bertujuan mengukur kekuatan hubungan antara dua variabel atau lebih, juga menunjukkan arah hubungan antara variabel bebas dan terikatnya. Dengan kata lain penelitian kausalitas mempertanyakan masalah sebab akibat (Kuncoro 2009).

\section{Populasi dan Sampel}

Populasi ialah sejumlah penduduk atau individu yang paling sedikit mempunyai suatu sifat yang sama. Jadi populasi adalah jumlah keseluruhan dan unit analisis yang ciri-cirinya akan diduga (Kuncoro, 2009). Berdasarkan pendapat ahli tersebut, populasi dalam penelitian ini adalah populasi yang menurut sifatnya merupakan populasi yang homogen. Dan populasi dalam penelitian ini adalah pelanggan Swalayan Larisso Ambulu Jember yang pernah berbelanja minimal 5 kali. Pemilihan lokasi populasi ini berdasarkan pada suatu pertimbangan yang logis yaitu peneliti mendapatkan kemudahan dalam hal memperoleh data yang dipergunakan dalam penelitian sehingga dapat memberikan manfaat berdasarkan keterbatasan biaya, waktu dan tenaga.

Dalam penelitian ini sampel yang diambil diharapkan dapat menggambarkan hasil yang sesungguhnya dari populasi (Kuncoro, 2009). Sekaran (2006) memberikan acuan umum untuk menentukan ukuran minimal sample, ukuran sample sebaiknya 20x lebih besar dari jumlah variabel bebas dalam penelitian. Ukuran sampel yang layak dalam penelitian adalah antara 30 sampai 500 (Sugiono, 2010:52). Berikut ini perhitungan jumlah sampel berdasarkan pendapat Sekaran (2006). Berdasarkan acuan tersebut maka sampel penelitian ini sebesar 20 kali jumlah variabel maka sample yang akan digunakan sebanyak 60 pelanggan.

\section{Uji Validitas}

Validitas didefinisikan sebagai ukuran seberapa kuat suatu alat tes melakukan fungsi ukurannya. Model pengujian menggunakan pendekatan Pearson Correlation untuk menguji validitas pernyataan kuesioner. Uji validitas digunakan untuk mengukur sah atau tidaknya suatu kuesioner.

\section{Uji Reliabilitas}

Apabila validitas telah diperoleh, maka peneliti harus mempertimbangkan pula pengukuran reliabilitas. Reliabilitas menunjukkan pada satu pengertian bahwa suatu 
instrumen cukup dapat dipercaya untuk digunakan sebagai alat pengumpul data karena instrumen tersebut sudah baik. Pengujian reliabilitas bertujuan untuk mengetahui konsistensi hasil pengukuran variabel-variabel.

\section{Analisis Regresi Linier Berganda}

Untuk mengetahui atau mengukur pengaruh antara variabel terikat (Y) dengan beberapa variabel bebas $(\mathrm{X})$, maka jenis analisis yang digunakan adalah analisis regresi berganda (Ghozali, 2013). Model persamaan regresi yang digunakan dapat dirumuskan sebagai berikut: $Y=\alpha+\beta_{1} X_{1}+\beta_{2} X_{2}+\beta_{3} X_{3}+$ e.

\section{Analisis Koefisien Determinasi $\left(\mathbf{R}^{2}\right)$}

Koefisien determinasi $\left(\mathrm{R}^{2}\right)$ pada intinya mengukur seberapa jauh kemampuan model dalam menerangkan variasi variabel terikat. Nilai koefisien determinasi adalah antara nol dan satu. Nilai $\left(\mathrm{R}^{2}\right)$ yang kecil berarti kemampuan variabel-variabel bebas (kualitas layanan, harga dan lokasi) dalam menjelaskan variasi variabel terikat (loyalitas konsumen) amat terbatas. Begitu pula sebaliknya, nilai yang mendekati satu berarti variabel-variabel bebas memberikan hampir semua informasi yang di butuhkan untuk memeprediksi variasi variabel terikat.

\section{HASIL DAN PEMBAHASAN}

\section{Hasil Uji Validitas dan Uji Relibilitas}

Hasil pengujian uji validitas menunjukkan bahwa korelasi antara masing-masing indikator terhadap total skor konstruk dari setiap variabel menunjukkan hasil yang valid, karena $r_{\text {hitung }}>r_{\text {tabel }}$ dan nilai signifikansi $<0,05$. Sehingga dapat disimpulkan bahwa semua item pernyataan dinyatakan valid.

Hasil uji reliabilitas tersebut menunjukkan bahwa semua variabel mempunyai koefisien Alpha yang cukup atau memenuhi kriteria untuk dikatakan reliabel yaitu di atas 0,700, sehingga untuk selanjutnya item-item pada masing-masing konsep variabel tersebut layak digunakan sebagai alat ukur.

\section{Hasil Analisis Regresi Linier Berganda}

Model persamaan regresi yang baik adalah yang memenuhi persyaratan asumsi klasik, antara lain semua data berdistribusi normal, model harus bebas dari gejala multikolinearitas dan terbebas dari heterokedastisitas. Dari analisis sebelumnya telah 
terbukti bahwa model persamaan yang diajukan dalam penelitian ini telah memenuhi persyaratan asumsi klasik sehingga model persamaan dalam penelitian ini sudah dianggap baik. Analisis regresi digunakan untuk menguji hipotesis tentang pengaruh secara parsial variabel bebas terhadap variabel terikat. Berdasarkan estimasi regresi linier berganda dengan program SPSS versi 20,0 diperoleh hasil sebagai berikut:

\section{Tabel 1: Hasil Analisis Regresi Linier Berganda}

\begin{tabular}{|c|l|c|}
\hline No & \multicolumn{1}{|c|}{ Variabel } & Koefisien Regresi \\
\hline $\mathbf{1}$ & Konstanta & 2,000 \\
\hline $\mathbf{2}$ & Kualitas Layanan $\left(\mathrm{X}_{1}\right)$ & 0,207 \\
\hline $\mathbf{3}$ & Komitmen Pelanggan $\left(\mathrm{X}_{2}\right)$ & 0,162 \\
\hline $\mathbf{4}$ & Kepercayaan Pelanggan $\left(\mathrm{X}_{3}\right)$ & 0,515 \\
\hline
\end{tabular}

Sumber: Data Diolah.

\section{Hasil Analisis Koefisien Determinasi}

Koefisien determinasi merupakan besaran yang menunjukkan besarnya variasi variabel dependen yang dapat dijelaskan oleh variabel independennya. Dengan kata lain, koefisien determinasi ini digunakan untuk mengukur seberapa jauh variabel-variabel bebas dalam menerangkan variabel terikatnya. Hasil perhitungan dapat diketahui bahwa koefisien determinasi yang diperoleh sebesar 0,769 . Hal ini berarti 76,9\% variasi variabel loyalitas pelanggan dapat dijelaskan oleh kualitas layanan, komitmen pelanggan, dan kepercayaan pelanggan, sedangkan sisanya sebesar 0,231 atau $23,1 \%$ diterangkan oleh variabel lain yang tidak diajukan dalam penelitian ini.

\section{Pembahasan}

\section{Pengaruh Kualitas Layanan Terhadap Loyalitas Pelanggan.}

Hasil pengujian ini membuktikan bahwa kualitas layanan mempunyai pengaruh terhadap loyalitas pelanggan. Artinya bahwa kualitas layanan yang meliputi petugas cekatan dalam melayani pelanggan, petugas sigap membantu pelanggan yang mengalami kesulitan, keramahan dirasakan pelanggan ketika berbelanja dan petugas memberikan perhatiannya secara penuh kepada pelanggan, berpengaruh terhadap loyalitas pelanggan. Kecekatan petugas dalam melayani pelanggan memberikan efek psikologis ke pelanggan, bahwa ketika mereka mengalami kesulitan dalam berbelanja akan dibantu serta dilayani dengan maksimal oleh petugas. Yang tidak boleh ditinggalkan adalah keramahan kepada pelanggan sangat penting agar tercipta suasana yang nyaman. Perhatian petugas kepada pelangaan juga harus diperhatikan, baik itu berupa tanggapan atas keluhan, komplain dari pelanggan ataupun pertanyaan seputar produk yang dijual. Hasil penelitian ini tidak 
sejalan dengan penelitian yang dilakukan Qomariah (2012) yang menyatakan bahwa kualitas layana tidak berpengaruh terhadap loyalitas pelanggan.

\section{Pengaruh Komitmen Pelanggan Terhadap Loyalitas Pelanggan}

Hasil pengujian ini membuktikan bahwa ada pengaruh komitmen pelanggan terhadap loyalitas pelanggan. Artinya bahwa komitmen pelanggan yang meliputi adanya ketertarikan kepada produk yang dijual, pelanggan merasa bagian dari swalayan, yang pertama terlintas ketika akan membeli sesuatu adalah membeli di Swalayan Larisso Ambulu Jember, dan produk yang dijual di Swalayan Larisso Ambulu Jember terjangkau secara ekonomi, berpengaruh terhadap loyalitas pelanggan. Produk yang dijual di Swalayan Larisso Ambulu Jember hendaknya adalah produk yang dapat menarik perhatian untuk dibeli baik itu dari segi harga, tampilan maupun merek. Adanya keterikatan emosional antara pelanggan dan swalayan merupakan aspek penting yang harus dibangun agar pelanggan tidak berpindah ke swalayan lain.

\section{Pengaruh Kepercayaan Pelanggan Terhadap Loyalitas Pelanggan}

Hasil pengujian ini membuktikan bahwa ada pengaruh kepercayaan pelanggan terhadap loyalitas pelanggan. Artinya bahwa kepercayaan pelanggan yang meliputi petugas selalu berkomunikasi dengan baik dengan pelanggan, semua informasi yang diberikan oleh petugas terkait produk benar adanya, petugas selalu bersikap welcome terhadap pelanggan, dan selalu menerima ketika ada komplain dari pelanggan, berpengaruh terhadap loyalitas pelanggan. Kepercayaan pelanggan antara swalayan dengan pelanggan dibangun dari komunikasi yang baik. Jadi swalayan dalam hal ini petugas hendaknya membangun suatu komunikasi yang baik dengan pelanggannya. Komunikasi ini bersifat melayani dari sudut pandang pelanggan.

\section{KESIMPULAN DAN SARAN}

\section{Kesimpulan}

Dari pengujian secara statistik yang telah dilakukan, maka dapat ditarik kesimpulan sebagai berikut:

1. Kualitas layanan, komitmen, dan kepercayaan secara simultan berpengaruh terhadap loyalitas pelanggan. Hasil temuan ini mendukung penelitian yang menyatakan Kualitas layanan, komitmen, dan kepercayaan secara simultan berpengaruh terhadap loyalitas pelanggan. 
2. Kualitas layanan, komitmen, dan kepercayaan secara parsial berpengaruh terhadap loyalitas pelanggan. Hasil temuan ini mendukung penelitian yang menyatakan Kualitas layanan, komitmen, dan kepercayaan secara parsial berpengaruh terhadap loyalitas pelanggan.

\section{Saran}

Berdasarkan penelitian yang telah dilakukan oleh peneliti, maka saran yang dapat diberikan Swalayan Larisso Ambulu Jember dari penelitian ini, yaitu hendaknya perusahaan dalam upaya menjaga loyalitas pelanggan lebih menitikberatkan pada kualitas layanan, komitmen, dan kepercayaan, sehingga dengan lebih memerhatikan kualitas layanan, komitmen, dan kepercayaan diharapkan akhirnya akan dapat meningkatkan loyalitas pelanggan.

Adapun yang perlu diperhatikan oleh Swalayan Larisso Ambulu Jember terkait hasil penelitian meliputi:

1. Kualitas layanan,

a. Kecekatan petugas dalam melayani pelanggan memberikan efek psikologis ke pelanggan, bahwa ketika mereka mengalami kesulitan dalam berbelanja akan dibantu serta dilayani dengan maksimal oleh petugas.

b. Keramahan kepada pelanggan sangat penting agar tercipta suasana yang nyaman. Perhatian petugas kepada pelangaan juga harus diperhatikan, baik itu berupa tanggapan atas keluhan, komplain dari pelanggan ataupun pertanyaan seputar produk yang dijual

2. Komitmen

a. Produk yang dijual di Swalayan Larisso Ambulu Jember hendaknya adalah produk yang dapat menarik perhatian untuk dibeli baik itu dari segi harga, tampilan maupun merek.

b. Adanya keterikatan emosional antara pelanggan dan swalayan merupakan aspek penting yang harus dibangun agar pelanggan tidak berpindah ke swalayan lain

3. Kepercayaan

a. Kepercayaan antara swalayan dengan pelanggan dibangun dari komunikasi yang baik. 
b. Swalayan dalam hal ini petugas hendaknya membangun suatu komunikasi yang baik dengan pelanggannya.

c. Komunikasi ini bersifat melayani dari sudut pandang pelanggan.

4. Bagi pengmbangan ilmu

Dari penelitian ini dapat dijadikan wacana dan refrensi ilmiah bagi pihak yang akan melakukan penelitian

\section{DAFTAR PUSTAKA}

Affandi, Lutfi. 2011. Pengaruh Komitmen Relasi, Kualitas Layanan, Dan Kepercayaan Terhadap Loyalitas Konsumen: Studi Pada PT. Teduh Makmur Semarang. Skripsi Fakultas Ekonomi Universitas Diponegoro, Semarang.

Barnes, James G.. 2001. Secret Of Customer Relationship Management. Andi : Yogyakarta.

Dwyer, F. Robert, Shurr, Paul H. \& Oh, Sejo. 1987. Developing Buyer-Seller Relationships. Journal of Marketing, 51 (2), 11-27.

Ghozali, Imam. 2013. Aplikasi Analisis Multivariat dengan Program IBM SPSS 21 Update PLS Regresi. Universitas Diponegoro. Semarang.

Griffin, Jill. 2005. Customer Loyalty: Menumbuhkan dan Mempertahankan Kesetiaan Pelanggan Edisi Revisi dan Terbaru. Diterjemahkan oleh Dr. Dwi Kartini Yahya. Erlangga, Jakarta.

Kotler, Philip. 2005. Manajamen Pemasaran, Jilid 1 dan 2. PT. Indeks. Kelompok Gramedia, Jakarta.

Kuncoro, Mudrajat. 2009. Metode Riset Untuk Bisnis \& Ekonomi. Erlangga. Jakarta.

Lestari. 2015. Pengaruh Komitmen Dan Kepercayaan Terhadap Loyalitas Konsumen Di Swalayan Relasi Jaya Pabelan. Skripsi Fakultas Ekonomi Dan Bisnis Program Studi Manajemen Universitas Muhammadiyah Surakarta.

Morgan, Robert M. \& Hunt, Shelby D. 1994. The Commitment-Trust Theory Of Relationship Marketing. Journal of Marketing, 58, 20-38.

Prasetyo, Widiyanto Bangun. 2012. Pengaruh Kualitas Pelayanan, Kepercayaan, dan Kepuasan terhadap Loyalitas Pelanggan (Studi Pada Swalayan Luwes Purwodadi).

Qomariah, Nurul. 2101. Pengaruh Kualitas Layanan dan Citra Institusi Terhadap Kepuasan dan Loyalitas Pelanggan. Jurnal Aplikasi Manajemen. Vol. 10. No. 1 Maret 
Schiffman, Leon dan Kanuk, Leslie Lazar. 2004. Perilaku Konsumen. Edisi ketujuh. Cetakan kedua, PT Indeks, Jakarta.

Sekaran, Uma. 2006. Research Methods For Business. Jilid 1. Edisi 4. Salemba Empat, Jakarta.

Setyani, Lintang Ayu. 2014. Analisis Pengaruh Kualitas Pelayanan Dan Kepercayaan Terhadap Loyalitas Pelanggan Melalui Kepuasan Pelanggan (Studi Pada Griya Kecantikan Aura Kota Semarang). Skripsi Fakultas Ekonomika Dan Bisnis Universitas Diponegoro, Semarang.

Sugiyono, 2012. Metode Penelitian Kuantitatif, Kualitatif Dan R \& D. Alfabeta. Bandung. 